\title{
The Catalytic Mechanism of Intercalated Chlorine Anions as Active Basic Sites in Mgal-layered Double Hydroxide for COS Hydrolysis
}

\section{Changming Li}

Beijing Technology and Business University

\section{Shuying Zhao}

Beijing Technology and Business University

\section{Xiaolong Yao}

Beijing Technology and Business University

Li He

Beijing Technology and Business University

\section{Simin $\mathrm{Xu}$}

Beijing University of Chemical Technology

\section{Xianbao Shen}

Beijing Technology and Business University

\section{Zhiliang Yao ( $\nabla$ yaozhl@th.btbu.edu.cn )}

Beijing Technology and Business University https://orcid.org/0000-0001-5125-8245

\section{Research Article}

Keywords: COS hydrolysis, Layered double hydroxides, Basic sites, Catalytic mechanism

Posted Date: July 26th, 2021

DOl: https://doi.org/10.21203/rs.3.rs-680303/v1

License: (c) (i) This work is licensed under a Creative Commons Attribution 4.0 International License. Read Full License 


\section{Abstract}

In order to make clear the role of intercalated anions in layered double hydroxides (LDHs) for catalytic hydrolysis of COS, the adsorption and reaction characteristics of COS over the simple $\mathrm{Mg}_{2} \mathrm{Al}-\mathrm{Cl}-\mathrm{LDH}$ model catalyst were studied by both theoretical and experimental methods. Density functional theory (DFT) calculations by CASTEP found that the chloride ions in LDH function as the key Brønsted-base sites to activate the adsorbed $\mathrm{H}_{2} \mathrm{O}$ with enlarged bond length and angle, facilitate the dissociative adsorption of intermediates including mono-thiocarbonic acid (MTA) and hydrogen thiocarbonic acid (HTA), and participate in the formation of transient states and subsequent hydrogen transfer process with decreased energy barriers during COS hydrolysis. COS hydrolysis will preferentially go through the dissociated intermediates of mono-thiocarbonates (MT) and hydrogen thiocarbonates (HT) with dramatically decreased energy barriers, and the rate-determining step of COS hydrolysis over $\mathrm{Mg}_{2} \mathrm{Al}-\mathrm{Cl}-$ $\mathrm{LDH}$ will be the nucleophilic addition of $\mathrm{C}=\mathrm{O}$ in $\mathrm{COS}$ by $\mathrm{H}_{2} \mathrm{O}(\mathrm{Ea}=1.10 \mathrm{eV})$. The experimental results further revealed that the apparent activation energy $(0.89 \mathrm{eV})$ of COS hydrolysis over $\mathrm{Mg}_{2} \mathrm{Al}-\mathrm{Cl}-\mathrm{LDH}$ is close to theoretical value $(1.10 \mathrm{eV})$, and the accumulated intermediates of MT, HT or carbonate were also observed by FT-IR around $1363 \mathrm{~cm}^{-1}$ on the used $\mathrm{Mg}_{2} \mathrm{Al}-\mathrm{Cl}-\mathrm{LDH}$, which are well in accordance with the theoretical prediction. The demonstrated participation of intercalated chlorine anions in the evolution of intermediates and transient states as Brønsted-base sites during COS hydrolysis will give new insight into the basic sites in LDH materials.

\section{Introduction}

Layered double hydroxides (LDHs) are a class of layered host-guest 2D materials, which have been considered as excellent solid base catalysts for many catalytic reactions such as aldol reaction, knoevenagel condensation, michael additions, transesterification reaction (Bing et al. 2018; Liu et al. 2014; Wang et al. 2011; Winter et al. 2006). The general formula of LDHs can be denoted as $\left[\mathrm{M}^{2+}{ }_{1-x^{3}} \mathrm{M}^{3+}\right.$ $\left.{ }_{x}(\mathrm{OH})_{2}\right]^{x+}\left(\mathrm{A}^{n-} x / n\right) \cdot m \mathrm{H}_{2} \mathrm{O}$, where $\mathrm{M}^{2+}$ and $\mathrm{M}^{3+}$ are metal cations such as $\mathrm{Mg}^{2+}, \mathrm{Ni}^{2+}, \mathrm{Mn}^{2+}, \mathrm{Zn}^{2+}$, or $\mathrm{Al}^{3+}$, $\mathrm{Ga}^{3+}, \mathrm{Fe}^{3+}, \mathrm{Cr}^{3+}$ occupying octahedral positions in hydroxide layers; $x$ is the molar ratio of the trivalent cation $\mathrm{M}^{3+} /\left(\mathrm{M}^{2+}+\mathrm{M}^{3+}\right)$, and $A$ denotes interlayer charge-compensating anions (Benhiti et al. 2020; Chaillot et al. 2020; Yan et al. 2010). Traditionally, the hydroxyl groups in LDHs were regarded as the active basic sites participating in catalytic reaction (Rao et al. 1998; Winter et al. 2005). However, Moraes et al. (2016), Costa et al. (2012) and Liu et al. (2020) have recently revealed that the most basic sites in LDHs are the interlayer anions $\left(\mathrm{PO}_{4}{ }^{3-}, \mathrm{CO}_{3}{ }^{2-}, \mathrm{Cl}^{-}\right)$rather than hydroxyl group in the layer through the structural analysis by Density functional theory (DFT). Therefore, how the intercalated anions function as the basic sites is still an unclear issue in these specific base-catalyzed reactions over LDH materials.

Carbonyl sulfide (COS) is one of the main malodorous and toxic organic sulfur compounds in industrial gases, which may poison the catalysts as well as cause serious environmental pollution (Cheng et al. 2015; Harnisch et al. 1995; Labaki and Jeguirim 2017; Yao et al. 2015). The removal of COS through catalytic hydrolysis over the solid base catalysts is one of the most effective strategy with the 
advantages of high efficiency, low operation cost, and mild reaction condition in industry (Chiche and Schweitzer 2017; Li et al. 2020; Zhao et al. 2020). As the typical solid base catalyst, LDHs and its calcined mixed metal oxides (MMO) exhibit excellent catalytic activity for COS hydrolysis as reported by Wang et al. (2012), Zhao et al. (2013b) and Song et al. (2019). Recently, Mi et al. (2019) demonstrated the excellent activity and stability for COS hydrolysis over the mechanochemically synthesized MgAl-LDHs with intercalated $\mathrm{CO}_{3}{ }^{2-}$, and their outstanding performances were attributed to the abundant hydroxyl groups in LDHs. On the other hand, the study by Ryzhikov et al. (2011) about the activated LDHs containing $\mathrm{CO}_{3}{ }^{2-}$ implied that the $\mathrm{CO}_{3}{ }^{2-}$ ions at external surface may be the active sites for $\mathrm{COS}$ hydrolysis. Until now, the exact type of key basic sites in LDHs and their catalytic mechanism have remained largely unknown for COS hydrolysis.

It is generally believed that COS hydrolysis obeys the addition mechanism through the intermediates of the mono-thiocarbonic acid (MTA) and hydrogen thiocarbonic acid (HTA) (See their detailed structure in Fig. S1) (Guo et al. 2016; Svoronos and Bruno 2002). Recently, Song et al. (2017), Ning et al. (2017) and Song et al. (2019) have done well work to explore the catalytic reaction mechanism of COS hydrolysis over different oxide catalysts such as $\mathrm{Fe}_{2} \mathrm{O}_{3}, \mathrm{CeO}_{2}, \mathrm{MgAlCe}$ by DFT, and the undissociated MTA and HTA were considered as intermediates during the catalytic hydrolysis of COS. However, many experiment results by infrared spectrometer indicated the existence of the dissociated intermediates of monothiocarbonates (MT) or hydrogen thiocarbonates (HT) during COS hydrolysis over the oxide catalysts (Aboulayt et al. 1996; Liu et al. 2007; Toops and Crocker 2008; Zhao et al. 2020). In addition, early research by George (1974) also proposed the hydroxyl involved nucleophilic addition mechanism through the dissociated intermediates of MT over alumina. Thus, the reaction path of COS hydrolysis through these dissociated intermediates of MT/HT is also possible and should be considered over the basic sites in LDHs.

In this work, the simple chlorine intercalated $\mathrm{Mg}_{2} \mathrm{Al}-\mathrm{Cl}-\mathrm{LDH}$ is chosen and prepared as the model catalyst to identify the active basic sites and make clear their catalytic mechanism for COS hydrolysis over LDH materials. The different adsorption configurations of reactants, intermediates and products were explored by DFT to make sure their best adsorption sites and most likely existence forms on $\mathrm{Mg}_{2} \mathrm{Al}-\mathrm{Cl}$-LDH surface. Moreover, the reaction pathways through both the undissociated and dissociated intermediates were considered, and the corresponding transient states and activation energies were calculated to find out the most possible reaction channels and rate-determining step for COS hydrolysis over the chlorine intercalated $\mathrm{LDH}$ material. In addition, the $\mathrm{Mg}_{2} \mathrm{Al}-\mathrm{Cl}-\mathrm{LDH}$ were prepared by coprecipitation method to evaluate its catalytic performance and apparent activation energy, and the accumulated reaction intermediates in the used $\mathrm{Mg}_{2} \mathrm{Al}-\mathrm{Cl}-\mathrm{LDH}$ were also detected by infrared spectroscopy. The results of this work reveal that the chlorine ions in $\mathrm{Mg}_{2} \mathrm{Al}-\mathrm{Cl}-\mathrm{LDH}$ act as the crucial basic sites to activate $\mathrm{H}_{2} \mathrm{O}$ molecule and participate in the evolution of intermediates and transient states during COS hydrolysis, which will give new insight into the basic sites in LDHs materials.

\section{Method}




\subsection{Computational Model}

The computational model of $\mathrm{Mg}_{2} \mathrm{Al}-\mathrm{Cl}-\mathrm{LDH}$ was constructed according to the previous report by Yan et al. (2010). The $2 \mathrm{H}$-polytyped model was chosen using the atomic coordinates of naturally occurring sjöegrenite with the unit cell parameters: $a=b=0.3100 \mathrm{~nm}, c=1.560 \mathrm{~nm}, a=\beta=90 \rrbracket, \gamma=120 \bigotimes, P 63 / \mathrm{mmc}$ space group (Taylor 1973). In geometry optimization of the compounds, all atoms and unit cell parameters were relaxed. The final model of $\mathrm{Mg}_{2} \mathrm{Al}-\mathrm{Cl}-\mathrm{LDH}$ was obtained as shown in Fig. $1 \mathrm{~A}-\mathrm{B}$, and the calculated cell parameters for these compounds are summarized in Table S1. As the preferentially exposed crystal face, the $\left(\begin{array}{lll}0 & 0 & 3\end{array}\right)$ face of $\mathrm{Mg}_{2} \mathrm{Al}-\mathrm{Cl}-\mathrm{LDH}$ was cut with $\mathrm{p}(2 \times 2 \times 1)$ supercells, and the vacuum region between slabs is $20 \AA$. Before the adsorption and reaction of COS, all the atoms in the cut cell were relaxed as shown in Fig. 1B1-B2.

\subsection{Computational Method}

The first-principle DFT calculations were performed with the plane wave method in Cambridge Sequential Total Energy Package (CASTEP) (Segall et al. 2002). The Perdew-Burke-Ernzerhof (PBE) in generalized gradient approximation (GGA) was used as the exchange-correlation functional (Payne et al. 1992; Perdew et al. 1996). The Tkatchenko Scheffler method was used for the DFT dispersion correction to deal with the hydrogen bonding and van der Waals interactions in LDHs (Tkatchenko and Scheffler 2009). The ionic cores are described by ultrasoft pseudopotentials, and the BFGS algorithm was used to search the potential energy surface during optimization (Anglada and Bofill 1998; Bajdich et al. 2013; García-Mota et al. 2012; Valdés et al. 2008). The calculation parameters are with the energy tolerance of $1 \times 10^{-5} \mathrm{eV}$ per atom, a maximum force tolerance of $0.03 \mathrm{eV} / \AA$, and a maximum displacement tolerance of $1 \times 10^{-3} \AA$. The k-point meshes used for the Brillouin zone integrations are $3 \times 3 \times 1$, and a Fermi smearing of $0.1 \mathrm{eV}$ and the cut-off energy of $340 \mathrm{eV}$ are used according to the results by Liu et al. (2020). Before geometry optimization of molecules, a periodic cube cell with the side length of $20 \AA$ was built. The molecular geometries of the reactants, transition states (TS), intermediate complexes (IM), and products were calculated and optimized using the same method and parameters as above by DFT. The TS Search with the complete Linear synchronous transit/Quadratic synchronous transit (LST/QST) method was used to find the transition states connect to the intended reactants and products, and the TS Confirmation were executed to confirm the found transition states. The adsorption energy $\left(E_{a b s}\right)$ was defined as Eq. 1. $E_{\text {adsorbate/catalyst }}$ is the total energy of the adsorbate/catalyst system after the gas molecule being adsorbed on model catalyst. $E_{\text {adsorbate }}$ is the energy of gas molecule and $E_{\text {catalyst }}$ is the energy of the model catalyst after geometry optimization.

$E_{\text {abs }}=E_{\text {adsorbate/catalyst }}-E_{\text {adsorbate }}-E_{\text {catalyst }}(1)$

\subsection{Experimental Method}

All inorganic chemical compounds (e.g., $\mathrm{NaOH}, \mathrm{MgCl}_{2} \cdot 6 \mathrm{H}_{2} \mathrm{O}$ and $\mathrm{AlCl}_{3} \cdot 6 \mathrm{H}_{2} \mathrm{O}$ ) were purchased from Macklin (Shanghai) without further purification. To avoid the introduction of $\mathrm{CO}_{3}{ }^{2-}$ in $\mathrm{LDHs}$, the deionized 
water was boiled before use in all the experimental processes. $\mathrm{Mg}_{2} \mathrm{Al}-\mathrm{Cl}-\mathrm{LDH}$ was synthesized by the coprecipitation method (Jaymand 2011). Typically, solution A was obtained by dissolving $0.16 \mathrm{M}$ $\mathrm{MgCl}_{2} \cdot 6 \mathrm{H}_{2} \mathrm{O}$ and $0.08 \mathrm{M} \mathrm{AlCl}_{3} \cdot 6 \mathrm{H}_{2} \mathrm{O}$ in $200 \mathrm{~mL}$ deionized water. Solution $\mathrm{B}$ contained $1 \mathrm{M} \mathrm{NaOH}$ in 200 $\mathrm{mL}$ deionized water. Then, solution $\mathrm{B}$ was added dropwise to solution $\mathrm{A}$ under vigorous stirring at room temperature, and the resulting suspension was stirred at $60^{\circ} \mathrm{C}$ for $2 \mathrm{~h}$. Subsequently, the suspension was transferred to a sealed Teflon aging at $105^{\circ} \mathrm{C}$ for $12 \mathrm{~h}$. The precipitate was filtered out, washed several times with deionized water until filtrate is neutral, and dried at $100^{\circ} \mathrm{C}$ for $12 \mathrm{~h}$ to obtain the $\mathrm{Mg}_{2} \mathrm{Al}-\mathrm{Cl}-\mathrm{LDH}$.

The crystal structure of the as-synthesized $\mathrm{Mg}_{2} \mathrm{Al}-\mathrm{Cl}-\mathrm{LDH}$ was confirmed by an X-ray diffraction analyzer (XRD, Smartlab) with a scanning rate of $0.02 \%$ in $5-90^{\circ}$ for $2 \theta$ at $40 \mathrm{kV}$ and $200 \mathrm{~mA}$. The scanning electron microscope (SEM, JSM-7800prime) with an accelerating voltage of $15 \mathrm{kV}$ was used to observe the morphology of $\mathrm{Mg}_{2} \mathrm{Al}-\mathrm{Cl}-\mathrm{LDH}$. The accumulated intermediate species in the used $\mathrm{Mg}_{2} \mathrm{Al}-\mathrm{Cl}-\mathrm{LDH}$ after COS hydrolysis were detected by the fourier transform infrared spectrometer (FT-IR, Tensor27, Bruker).

The catalytic performance of COS hydrolysis over $\mathrm{Mg}_{2} \mathrm{Al}-\mathrm{Cl}-\mathrm{LDH}$ was evaluated in the fixed bed reactor (10 $\mathrm{mm}$ in inner diameter) at atmospheric pressure using $0.5 \mathrm{~g}$ of catalyst ( $20-40 \mathrm{mesh}$ ). The total gas hourly space velocity is $4500 \mathrm{~h}^{-1}$ with $500 \mathrm{ppm} \mathrm{COS}$, and the $\mathrm{H}_{2} \mathrm{O}$ was injected into the reactor from a thermostatic water at $25^{\circ} \mathrm{C}$ with the water vapor content of $2.9 \%$. The concentration of COS was continually monitored on line by a gas chromatograph (SP-3420A) equipped with a flame photometric detector (FPD). The COS conversion was calculated as Eq. 2. The Arrhenius plots of COS hydrolysis over $\mathrm{Mg}_{2} \mathrm{Al}-\mathrm{Cl}-\mathrm{LDH}$ were obtained according to the data of COS conversion below $20 \%$ with the minimized effect of diffusion.

CoS conversion $(\%)=\left(\operatorname{COS}_{\text {inlet }}-\operatorname{COS}_{\text {outlet }}\right) / \cos _{\text {inlet }} \times 100 \%(2)$

\section{Results And Discussion}

\subsection{The adsorption configurations of reactants}

The adsorption is the first step for catalytic reaction, and the optimal adsorption configuration of $\mathrm{H}_{2} \mathrm{O} / \mathrm{COS}$ will help to identify the active basic sites in LDHs. The adsorption of $\mathrm{H}_{2} \mathrm{O}$, COS as well as $\mathrm{H}_{2} \mathrm{O}$ /COS at the different sites on the $\left(\begin{array}{lll}0 & 0\end{array}\right)$ face of $\mathrm{Mg}_{2} \mathrm{Al}$-Cl-LDH were explored as shown in Fig. 2, respectively. After geometry optimization of adsorbed $\mathrm{H}_{2} \mathrm{O}$ at $\mathrm{Mg}$ site, $\mathrm{Al}$ site and $\mathrm{Mg}$-Al bridge site (top view in Fig. 2A1-A3, side view in Fig. S2A1-A3), the two hydrogen atoms in $\mathrm{H}_{2} \mathrm{O}$ are drawn by the nearby chloride ion pair and are nearly in the same plane with chloride ions. At the same time, the oxygen in $\mathrm{H}_{2} \mathrm{O}$ interacts with the neighboring hydrogens in hydroxy groups of LDH through hydrogen bond (Hou et al. 2017; Nobeli et al. 2001). It is worth noting that the chloride ion pair significantly changes the structural parameter of $\mathrm{H}_{2} \mathrm{O}$ with longer bond distance of $\mathrm{O}-\mathrm{H}\left(\mathrm{L}_{\mathrm{O}-\mathrm{H}}\right)$ and larger bond angle of $\mathrm{H}-\mathrm{O}-\mathrm{H}\left(\theta_{\mathrm{H}-\mathrm{O}-\mathrm{H}}\right)$. Especially over the Mg-Al bridge sites (Fig. 2A3), the interaction between the $\mathrm{Cl}$ and $\mathrm{H}$ in $\mathrm{H}_{2} \mathrm{O}$ is the strongest with the shortest distance of $2.08 \AA$. Correspondingly, the $\mathrm{L}_{\mathrm{O}-\mathrm{H}}$ and $\theta_{\mathrm{H}-\mathrm{O}-\mathrm{H}}$ are enlarged by the 
chloride ion pair from $0.98 \AA$ and $104.6 \rrbracket$ in gaseous $\mathrm{H}_{2} \mathrm{O}$ to $1.00 \AA$ and $110.9 \bigotimes$ in adsorbed $\mathrm{H}_{2} \mathrm{O}$, respectively. Moreover, the adsorption of $\mathrm{H}_{2} \mathrm{O}$ over $\mathrm{Mg}$-Al bridge site possesses the lowest adsorption energy (-0.78 eV, Fig. 1A3). The enlarged $\mathrm{L}_{\mathrm{O}-\mathrm{H}} / \theta_{\mathrm{H}-\mathrm{O}-\mathrm{H}}$ as well as the strong adsorption of $\mathrm{H}_{2} \mathrm{O}$ will weaken the $\mathrm{O}-\mathrm{H}$ bond in $\mathrm{H}_{2} \mathrm{O}$ and facilitate its hydrolysis reaction with COS. These results clearly demonstrate the chloride ions in $\mathrm{LDH}$ can strongly interact with $\mathrm{H}$ atoms in adsorbed $\mathrm{H}_{2} \mathrm{O}$ molecule, enlarge the $\mathrm{L}_{\mathrm{O}-\mathrm{H}}$ and $\theta_{\mathrm{H}-\mathrm{O}-\mathrm{H}}$ in $\mathrm{H}_{2} \mathrm{O}$, and thus dramatically activate the $\mathrm{H}_{2} \mathrm{O}$ for COS hydrolysis, which acts as the active sites for adsorption of $\mathrm{H}_{2} \mathrm{O}$ in $\mathrm{Mg}_{2} \mathrm{Al}-\mathrm{Cl} \mathrm{LDH}$.

The adsorption of COS over the Mg site, Al site and OH site on LDH was shown in Fig. 2B1-B3 (top view) and Fig. S2B1-B3 (side view). It can be found that the oxygen in COS is also drawn by neighboring hydrogen of hydroxy groups in $\mathrm{LDH}$, but the repulsive force between the $\mathrm{S}$ atom in COS and chlorine ion in LDH make the nearby chlorine ion away from its original location. The structural parameters of adsorbed COS change little and the adsorption energies are in the range from $-0.27 \mathrm{eV}$ to $-0.19 \mathrm{eV}$, which are much smaller than that of the adsorbed $\mathrm{H}_{2} \mathrm{O}$. These results indicate the COS molecule weakly adsorbs on the LDH surface in comparison with $\mathrm{H}_{2} \mathrm{O}$.

The above results show the $\mathrm{H}_{2} \mathrm{O}$ can adsorb much stronger than COS over LDH surface, and $\mathrm{H}_{2} \mathrm{O}$ molecule will first occupy the optimal Mg-Al bridge site with the lowest adsorption energy. Figure 2C1-C3 shows the coadsorption of COS around the pre-adsorbed $\mathrm{H}_{2} \mathrm{O}$. Compared with the adsorption of the single $\mathrm{H}_{2} \mathrm{O}$ or $\mathrm{COS}$, both the $\mathrm{H}_{2} \mathrm{O}$ and COS are away from their original positions, indicating the repulsive force exists between the absorbed $\mathrm{H}_{2} \mathrm{O}$ and COS. The coadsorption energy of the three configurations are all lower than that of absorbed $\mathrm{H}_{2} \mathrm{O}$ in Fig. 2B1-B3, and the coadsorption of $\mathrm{COS}$ at the $\mathrm{OH}$ site possesses the lowest adsorption energy of $-0.86 \mathrm{eV}$. Another possible coadsorption model is the absorption of COS upon the adsorbed $\mathrm{H}_{2} \mathrm{O}$ as shown in Fig. $\mathrm{S} 3$, which is similar with the coadsorption of $\mathrm{H}_{2} \mathrm{O} / \mathrm{COS}$ on the $\mathrm{CeO}_{2}(110)$ surface reported by Song et al. (2017). It can be found that the adsorption energy $(-0.69 \mathrm{eV})$ is even higher than that for the adsorption of the single $\mathrm{H}_{2} \mathrm{O}$ at the $\mathrm{Mg}-\mathrm{Al}$ bridge site $(-0.78 \mathrm{eV}$, Fig. 2A3), which indicates the adsorption model of $\mathrm{COS}$ upon the adsorbed $\mathrm{H}_{2} \mathrm{O}$ will not be preferential. These results manifest both $\mathrm{H}_{2} \mathrm{O}$ and COS will preferentially coadsorb at the surface sites on $\mathrm{Mg}_{2} \mathrm{Al}-\mathrm{Cl}-\mathrm{LDH}$, and the further hydrolysis reaction at low temperature (30-250 खC) will follow the Langmuir-Hinshelwood reaction mechanism (Chiche and Schweitzer 2017; Rhodes et al. 2000; Svoronos and Bruno 2002).

The successful occurrence of a chemical reaction needs proper orientation and energy according to the collision theory of chemical reaction. Although the coadsorptionenergies of $\mathrm{H}_{2} \mathrm{O} / \mathrm{COS}$ are close, the geometrical configurations for the coadsorption of $\mathrm{COS}$ at $\mathrm{Mg}$ or Al sites (Fig.2C1-C2) are against the formation of conjugated structure during the nucleophilic addition of the $\mathrm{C}=\mathrm{O}$ or $\mathrm{C}=\mathrm{S}$. Thus, the coadsorption of $\mathrm{COS}$ atOH site (Fig.2C3) will be adopted as the optimal adsorption configuration (denoted as IM1) for COS hydrolysis. 
Figure2The geometrically optimized configurations of $\mathrm{H}_{2} \mathrm{O}$ (A1-A3), $\mathrm{COS}$ (B1-B3) and $\mathrm{H}_{2} \mathrm{O} / \mathrm{COS}$ (C1-C3) adsorbed at the different sites on $\left(\begin{array}{lll}0 & 0 & 3\end{array}\right)$ face of $\mathrm{Mg}_{2} \mathrm{Al}-\mathrm{Cl}-\mathrm{LDH}$ from top view with their adsorption energy labeled. (Atomic legend: $-\mathrm{Cl},-\mathrm{C},-\mathrm{S},-\mathrm{H},-\mathrm{O},-\mathrm{Al},-\mathrm{Mg}$.)

\subsection{The adsorption configurations of the possible intermediates}

The MTA and HTA are the main possible intermediates during COS hydrolysis as displayed by many reports (See their detailed structure in Fig. S1) (Deng et al. 2007; Guo et al. 2016). The possible adsorption configurations of these intermediates over the surface of $\mathrm{Mg}_{2} \mathrm{Al}-\mathrm{Cl}-\mathrm{LDH}$ will be explored in this part. Fig. S4 and Fig. 3 show the possible configurations of MTA adsorbed on the LDH surface. When the MTA was put parallelly up the LDH surface (Fig. S4A), the two $\mathrm{H}$ atoms of hydroxyl groups in MTA are drawn toward the neighbouring chlorine ion pair with the adsorption energy of $-1.02 \mathrm{eV}$, indicating the strong interaction between the $\mathrm{H}$ atoms in MTA and the $\mathrm{Cl}$ ions in LDH. After putting the MTA close to the chlorine ion pair vertically (Fig. S4B), the interaction between the two $\mathrm{H}$ atoms of hydroxyl groups in MTA and the nearby chlorine ion pair increases significantly with much lower adsorption energy of $-1.23 \mathrm{eV}$. The adsorption energy can further decrease to $-1.42 \mathrm{eV}$ if the MTA molecule is in the same plane with the chloride ions (Fig. S4C and Fig. 3A). It can also be seen from Fig. S4C that the $S$ and $O$ atoms in MTA can also interact with the nearby $\mathrm{H}$ atoms of surface hydroxyl in LDH with the bond length of $2.29 \AA$ and 1.69 $\AA$, respectively, which accounts for its decreased adsorption energy. Especially, the distance between $\mathrm{H}$ atoms in MTA and nearby $\mathrm{Cl}$ even achieves to $1.59 \AA$ together with the enlarged $\mathrm{O}-\mathrm{H}$ bond length in MTA from $0.99 \AA$ (original state) to $1.19 \AA$ (adsorbed state, Fig. 3A). The weakened O-H in MTA by Cl will make the hydrogen transfer in MTA easy during hydrolytic process. According to the above different adsorption configurations and their adsorption energies, MTA will preferentially adopt the lied adsorption configuration as shown in Fig. $3 \mathrm{~A}$.

Figure3The different geometrical configurations of MTA (A) and its two dissociative adsorption products of $\mathrm{MT} \sim \mathrm{HCl}(\mathrm{B}, \mathrm{C})$ on the $\left(\begin{array}{lll}0 & 0 & 3\end{array}\right)$ face of $\mathrm{Mg}_{2} \mathrm{Al}-\mathrm{Cl}-\mathrm{LDH}$ from top view together with their adsorption energies labeled. IM2a IM2c are the serial numbers of the possibleintermediates during CoS hydrolysis, which are labeled at the bottom right of each adsorption configuration. (Atomic legend: $-\mathbf{C l},-\mathbf{C},-\mathbf{S},-\mathbf{H},-\mathbf{O},-$ Al, -Mg.)

Considering the dissociative adsorption of MTA to form MT as observed by the experimental results of FT-IR (Liu et al. 2007; Rhodes et al. 2000; Zhao et al. 2020), the possible adsorption configurations of MT over $\mathrm{Mg}_{2} \mathrm{Al}-\mathrm{Cl}-\mathrm{LDH}$ are also explored. Fortunately, two possible adsorption configurations of MT (denoted as IM2b and IM2c) were found as shown in Fig. 3B-C by putting one of the hydroxyls in MTA much closer to $\mathrm{Cl}$ ion in LDH. Under the interaction of nearby chloride ion, any of the two hydrogen atoms in MTA can be dissociated to form adsorbed MT anion and hydrogen chloride $(\mathrm{HCl})$, which clearly manifests the $\mathrm{Cl}$ ions in LDHs function as the Brønsted-base sites to interact with the acidic MTA. Moreover, the bond length of the adsorbed $\mathrm{HCl}(1.36 \sim 1.38 \AA)$ is much longer that of gaseous $\mathrm{HCl}(1.27 \AA)$, implying the easy 
hydrogen transfer between MTA and MT HCl. To confirm this point, the transient state and activation energy of the hydrogen transfer between MTA and MT HCl was calculated as shown in Fig. S5, and the corresponding imaginary frequency of the transition state is shown in Table S2. The activation energies from MTA to MT HCl and from MT HCl to MTA are $0.05 \mathrm{eV}$ and $0.10 \mathrm{eV}$, respectively. The very small activation energies of both forward reaction and reverse reaction verify the easy hydrogen transfer as well as the dissociation equilibrium between adsorbed MTA and MT HCl on LDH. Therefore, the MT HCl can also be the intermediates during COS hydrolysis over $\mathrm{Mg}_{2} \mathrm{Al}-\mathrm{Cl}-\mathrm{LDH}$.

The possible adsorption configurations of other intermediates during COS hydrolysis over $\mathrm{Mg}_{2} \mathrm{Al}-\mathrm{Cl}-\mathrm{LDH}$ are shown in Fig. 4. The different configurations of $\mathrm{HTA}$ and their dissociated $\mathrm{HT} \sim \mathrm{HCl}$ can all be found over the LDH surface from Fig. 4A1 to Fig. 4B3. Similar with the dissociative adsorption of MTA, the $\mathrm{Cl}$ ions in LDHs also function as the Brønsted-base sites to take in the $\mathrm{H}$ atom from HTA. Moreover, the adsorption energies of the dissociated $\mathrm{HT} \sim \mathrm{HCl}(-0.99 \mathrm{eV} \sim-0.75 \mathrm{eV})$ are observably lower than that of undissociated HTA (-0.75 -0.69). The lower adsorption energies indicate that the dissociated $\mathrm{HT} \sim \mathrm{HCl}$ is more stable and will be the dominant species over LDH surface, which are well consistent with the experimental results (Liu et al. 2007; Rhodes et al. 2000). The transient states and activation energies of the hydrogen transfer between HTA and $\mathrm{HTA} \sim \mathrm{HCl}$ were also calculated as shown in Fig. S6. Their activation energies of both forward reaction and reverse reaction are also small from $0.08 \mathrm{eV}$ and $0.47 \mathrm{eV}$, implying the easy hydrogen transfer as well as the dissociation equilibrium between adsorbed $\mathrm{HTA}$ and $\mathrm{HA} \sim \mathrm{HCl}$ on $\mathrm{LDH}$. In addition, the final hydrolysis products $\left(\mathrm{H}_{2} \mathrm{~S}\right.$ and $\left.\mathrm{CO}_{2}\right)$ adsorbed on $\mathrm{Mg}_{2} \mathrm{Al}-\mathrm{Cl}-\mathrm{LDH}$ are also shown in Fig. $4 \mathrm{C}$, and its much higher adsorption energy of $-0.17 \mathrm{eV}$ indicates their easy desorption from the LDH surface, which is also supported by the experimental results by Fiedorow et al. (1984).

In brief, the MTA and HTA can strongly adsorbed in the same plane within the chloride ions on the LDH surface with the adsorption energies from $0.69 \mathrm{eV}$ to $1.49 \mathrm{eV}$. The MTA and HTA are inclined to dissociate and exist in the form of dissociated $\mathrm{MT} \sim \mathrm{HCl}$ and $\mathrm{HT} \sim \mathrm{HCl}$ with much lower adsorption energies on LDH, and the $\mathrm{Cl}$ ions in LDHs function as the Brønsted-base sites to take in the $\mathrm{H}$ atoms from MTA or HTA. The low energy barriers are from $0.05 \mathrm{eV}$ to $0.47 \mathrm{eV}$ between MTA/HTA and their dissociated MT/HT HCl on LDH, implying the existence of dissociation equilibrium for MTA and HTA adsorbed on LDH.

Figure4 The different geometrical configurations of HTA (A1, B1), their possible dissociative adsorption products of $\mathrm{HT} \sim \mathrm{HCl}(\mathrm{A} 2, \mathrm{~B} 2, \mathrm{~B} 3)$, and thefinal hydrolysis products $\left(\mathrm{H}_{2} \mathrm{~S}\right.$ and $\left.\mathrm{CO}_{2}\right)$ adsorbed on the $\left(\begin{array}{lll}0 & 0 & 3\end{array}\right)$ face of $\mathrm{Mg}_{2} \mathrm{Al}-\mathrm{Cl}-\mathrm{LDH}$ from top view together with their adsorption energies labeled. IM3a IM5 are the serial numbers of the possibleintermediates during COS hydrolysis, which are labeled at the bottom right of each adsorption configuration. (Atomic legend: $-\mathrm{Cl},-\mathrm{C},-\mathrm{S},-\mathrm{H},-\mathrm{O},-\mathrm{Al},-\mathrm{Mg}$.)

\subsection{The possible reaction channels}

Considering the existence of the dissociation equilibrium of MTA and HTA on LDH with small energy barriers $(<0.5 \mathrm{eV})$, the role of the dissociated $\mathrm{MT} \sim \mathrm{HCl}$ and $\mathrm{HT} \sim \mathrm{HCl}$ should be considered in the reaction mechanism of COS hydrolysis over $\mathrm{Mg}_{2} \mathrm{Al}-\mathrm{Cl}-\mathrm{LDH}$. This part will find out and compare the transition 
states and activation energies through/non-through the dissociated $\mathrm{MT} \sim \mathrm{HCl}$ and $\mathrm{HT} \sim \mathrm{HCl}$ to find the most possible reaction pathways for COS hydrolysis.

Figure 5 shows the transient states and activation energies through the dissociated $\mathrm{MT} \sim \mathrm{HCl}$ and $\mathrm{HT} \sim$ $\mathrm{HCl}$ for COS hydrolysis over the $\left(\begin{array}{ll}0 & 0\end{array}\right)$ face of $\mathrm{Mg}_{2} \mathrm{Al}-\mathrm{Cl}-\mathrm{LDH}$ together with their imaginary frequencies listed in Table S2. Normally, the first step for COS hydrolysis will be through the nucleophilic addition of $C$ $=\mathrm{O}$ or $\mathrm{C}=\mathrm{S}$ bond (Chiche and Schweitzer 2017). The energy barriers for the addition of $\mathrm{C}=\mathrm{O}$ and $\mathrm{C}=\mathrm{S}$ by $\mathrm{H}_{2} \mathrm{O}$ is $1.10 \mathrm{eV}$ (Fig. 5, TS1) and $1.52 \mathrm{eV}$ (Fig. S7, S-TS), respectively. Thus, the first step of CoS hydrolysis will preferentially occur through the nucleophilic addition of $\mathrm{C}=\mathrm{O}$ bond over $\mathrm{Mg}_{2} \mathrm{Al}-\mathrm{Cl}-\mathrm{LDH}$. Especially, it can be seen from the structure of TS1 that the chlorine ion also acts as Brønsted-base site and takes in one $\mathrm{H}$ atom from $\mathrm{H}_{2} \mathrm{O}$ to form active hydroxy, and the hydroxy attack $\mathrm{COS}$ and activate $\mathrm{C}=\mathrm{O}$ bond ultimately to form MTA (IM2a). The result is well in accord with the proposed reaction mechanism catalysed by hydroxy (George 1974; Zhao et al. 2013a). These results further confirm that the chloride ions in LDH can facilitate the activization and dissociation of $\mathrm{H}_{2} \mathrm{O}$, which is also supported by the adsorption configurations of reactants in Fig. 2.

For the second step of COS hydrolysis, the produced MTA (IM2a) will be easily dissociated to MT HCl (IM2b) by nearby $\mathrm{Cl}$ ion with very low energy barrier of $0.05 \mathrm{eV}(\mathrm{IM} 2 \mathrm{a} \rightarrow \mathrm{IM} 2 \mathrm{~b}$, Fig. S5). The adsorbed $\mathrm{HCl}$ can easily turn and form the adsorption configuration of $\mathrm{HT} \sim \mathrm{HCl}$ (TS2, IM3b) also with very low energy barrier of $0.15 \mathrm{eV}$. Then the hydroxyl in IM3b can rotate and form IM4b, and much higher resistance exists in the step with the activation energy of $0.79 \mathrm{eV}$ (TS3b). Through the dissociation equilibrium of HTA

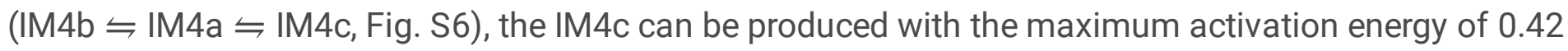
eV from IM4b to IM4a.

The last step for COS hydrolysis is the elimination reaction of sulfhydryl group in $\mathrm{HT}$ by the dissociated $\mathrm{HCl}$. The $\mathrm{C}$-S bond in $\mathrm{HT}$ will be broke after the $\mathrm{HCl}$ turns toward the $\mathrm{S}-\mathrm{H}$ with the activation energy of 0.84 $\mathrm{eV}$ (TS4c). Then hydrogen transfer occurs from $\mathrm{HCl}$ to hydrosulphonyl, and the final hydrolysis products $\left(\mathrm{H}_{2} \mathrm{~S}\right.$ and $\mathrm{CO}_{2}$, IM5) will be generated and desorbed from LDH surface with small energy barrier of $0.17 \mathrm{eV}$ (Fig. 4C). Meanwhile, the $\mathrm{Cl}$ ion is released from $\mathrm{HCl}$ to finish one catalytic cycle for COS hydrolysis.

By comparison, the transient states and activation energies of the reaction channels through the

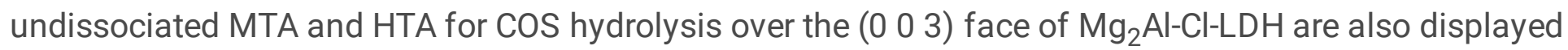
in Fig. S8. Without the participation of $\mathrm{Cl}$ ions from IM2a to IM5, all the energy barriers of each step are much higher than that of the reaction path through the dissociated $\mathrm{MT} \sim \mathrm{HCl}$ and $\mathrm{HT} \sim \mathrm{HCl}$. Specially, the activation energies of intramolecular hydrogen transfer from IM2a to IM3a and from IM4a to IM5 are 1.78 $\mathrm{eV}$ and $2.12 \mathrm{eV}$, respectively, which are even higher than that of COS hydrolysis in neutral water (Deng et al. 2007; Guo et al. 2016). The low adsorption energies as well as the hydrogen-bond interaction between MTA/HTA and LDH (Fig. 3 and Fig. 4) may confine the intramolecular hydrogen transfer without the help of $\mathrm{Cl}$ ions, which accounts for their high energy barriers. 
Figure5The transient states and activation energies of the reaction channel through the dissociated $\mathrm{MT} \sim \mathrm{HCl}$ and $\mathrm{HT} \sim \mathrm{HCl}$ for COS hydrolysisover the $\left(\begin{array}{lll}0 & 0 & 3\end{array}\right)$ face of $\mathrm{Mg}_{2} \mathrm{Al}-\mathrm{Cl}-\mathrm{LDH}$. (Atomic legend: $-\mathrm{Cl},-\mathrm{C},-\mathrm{S},-$ $\mathbf{H},-\mathbf{0}$. The elements in layer of LDH are not shown.)

According to the above results, the reaction channels are presented in Fig. 6 for hydrolysis of COS through MT/HT or MTA/HTA. Comparing the high energy barriers through the route of MTA/HTA (TS2a, $E a=1.78 \mathrm{eV}$ or TS4a, Ea $=2.12 \mathrm{eV}$ in Fig. S8), the energy barriers through the route of MT/HT are markedly decreased. The low energy barriers from IM2a to IM3b or from IM4a to IM5 are benefit from the participation of $\mathrm{Cl}$ ions in dissociative adsorption of MTA/HTA and subsequent hydrogen transfer process. The energy barriers for the rotation of hydroxyl in HTA or HT are close (TS3a, TS3b) because the $\mathrm{Cl}$ ions are not involved in any one of them. These results clearly demonstrate the COS hydrolysis will preferentially go through the dissociated intermediates of $\mathrm{MT} / \mathrm{HT} \sim \mathrm{HCl}$. In the reaction channel, the ratedetermining step of COS hydrolysis will be the nucleophilic addition of $\mathrm{C}=0$ bond in COS with the energy barrier of $1.10 \mathrm{eV}$, which is much lower than that of COS hydrolysis in neutral water (2.53 eV) (Deng et al. 2007).

In consideration of the dissociation of intermediates (Fig. 3 and Fig. 4) as well as the possible reaction path through the nucleophilic addition $\mathrm{C}=\mathrm{S}$ in $\mathrm{COS}$ (Fig. S7), the total reaction networks of COS hydrolysis over the $\left(\begin{array}{lll}0 & 0 & 3\end{array}\right)$ face of $\mathrm{Mg}_{2} \mathrm{Al}-\mathrm{Cl}$-LDH can be described in Fig. 7. In the reaction networks, the $\mathrm{H}_{2} \mathrm{O}$ and COS are strongly coadsorbed on the surface sites of $\mathrm{Mg}_{2} \mathrm{Al}-\mathrm{Cl}-\mathrm{LDH}$. COS hydrolysis will follow the Langmuir-Hinshelwood reaction mechanism, and preferentially occur through the nucleophilic addition $\mathrm{C}=\mathrm{O}$ instead of $\mathrm{C}=\mathrm{S}$ in $\mathrm{COS}$, which is also the rate-determining step. The dissociation equilibriums may exist among these adsorbed intermediates from IM2 to IM4, and the reaction routes through the dissociated intermediates will possess the lower energy barriers. The final products of $\mathrm{H}_{2} \mathrm{~S}$ and $\mathrm{CO}_{2}$ can be easy desorbed from LDH surface with very low energy barrier of $0.17 \mathrm{eV}$.

\subsection{The experiment results for COS hydrolysis over $\mathrm{Mg}_{2} \mathrm{Al}-\mathrm{Cl}-\mathrm{LDH}$.}

The $\mathrm{Mg}_{2} \mathrm{Al}-\mathrm{Cl}-\mathrm{LDH}$ was prepared for COS hydrolysis by coprecipitation method, and its structure and catalytic properties are shown in Fig. 8. All the peaks in the XRD pattern of Fig. $8 \mathrm{~A}$ can be indexed as a

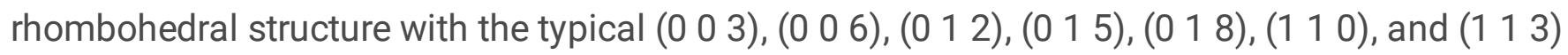
reflections at $2 \theta \approx 11.17,22.47,34.37,38.33,44.88,60.24,61.53^{\circ}$, respectively. And the interlayer spacing of $\left(\begin{array}{lll}0 & 0 & 3\end{array}\right)$ plane at $2 \theta=11.17^{\circ}$ is $0.79 \mathrm{~nm}$, which is consistent with the other reported $\mathrm{Mg}_{2} \mathrm{Al}-\mathrm{Cl}-$ LDH samples (Guo et al. 2011; Yue et al. 2017). No other crystalline phase was detected, indicating the high purity of the as-synthesized $\mathrm{Mg}_{2} \mathrm{Al}-\mathrm{Cl}-\mathrm{LDH}$. The SEM image (Fig. 8B) of $\mathrm{Mg}_{2} \mathrm{Al}-\mathrm{Cl}-\mathrm{LDH}$ also show the typical nanoplatelet morphology with a diameter of $200-400 \mathrm{~nm}$.

The catalytic performance of the $\mathrm{Mg}_{2} \mathrm{Al}-\mathrm{Cl}-\mathrm{LDH}$ for COS hydrolysis is shown in Fig. 8C. The COS conversion increases rapidly above $50^{\circ} \mathrm{C}$, and reaches $100 \%$ at $130^{\circ} \mathrm{C}$. According to the Arrhenius plots as shown in Fig. 8D, the apparent activation energy for COS hydrolysis over $\mathrm{Mg}_{2} \mathrm{Al}-\mathrm{Cl}-\mathrm{LDH}$ were calculated to be $85.6 \mathrm{~kJ} / \mathrm{mol}$ (or $0.89 \mathrm{eV}$ ), which is close to the calculated theoretical value of $1.10 \mathrm{eV}$ in Fig. 5. The 
activity of the $\mathrm{Mg}_{2} \mathrm{Al}-\mathrm{Cl}-\mathrm{LDH}$ is much lower than that of $\mathrm{MgAl}^{-\mathrm{CO}_{3}}$-LDHs reported by Mi et al. (2019), which may be owing to the stronger alkalinity of intercalated $\mathrm{CO}_{3}{ }^{2-}$ than $\mathrm{Cl}^{-1}$ ( $\mathrm{Liu}$ et al. 2020). The FT-IR spectra were used to identify the accumulated intermediate products in the used $\mathrm{Mg}_{2} \mathrm{Al}-\mathrm{Cl}-\mathrm{LDH}$ after performance evaluation as shown in Fig. $8 \mathrm{E}$. As for the fresh $\mathrm{Mg}_{2} \mathrm{Al}-\mathrm{Cl}-\mathrm{LDH}$, the multiple peaks in the range of $2800-3800 \mathrm{~cm}^{-1}$ and $470-1100 \mathrm{~cm}^{-1}$ can be assigned to the vibrations of surface hydroxy $/ \mathrm{H}_{2} \mathrm{O}$ and metallic-oxygen lattice, respectively. Comparing with the fresh $\mathrm{Mg}_{2} \mathrm{Al}-\mathrm{Cl}-\mathrm{LDH}$, the multiple peaks of surface hydroxy $/ \mathrm{H}_{2} \mathrm{O}$ in the range of $2800-3800 \mathrm{~cm}^{-1}$ strongly increase, indicating the strong adsorption of $\mathrm{H}_{2} \mathrm{O}$ on $\mathrm{Mg}_{2} \mathrm{Al}-\mathrm{Cl}-\mathrm{LDH}$. The result is well coincident with the low adsorption energy of $\mathrm{H}_{2} \mathrm{O}$ from $-0.68 \mathrm{eV}$ to $-0.78 \mathrm{eV}$ over the $\left(\begin{array}{lll}0 & 0 & 3\end{array}\right)$ surface of $\mathrm{Mg}_{2} \mathrm{Al}-\mathrm{Cl}-\mathrm{LDH}$ as shown in Fig. 2. Meanwhile, very strong peaks around $1363 \mathrm{~cm}^{-1}$ appear, which can be attributed to the accumulated intermediate products including the MT, HT, or carbonate (Mi et al. 2019; Zhao et al. 2020). According to the data in Fig. 5, the activation energies from IM2a to IM4c through the route of MT/HT are much lower than that from IM1 to IM2a or from IM4c to IM5, which indicates that the accumulation of these intermediates in $\mathrm{Mg}_{2} \mathrm{Al}-\mathrm{Cl}-\mathrm{LDH}$ (e.g., MT and $\mathrm{HT}$ ) is reasonable during COS hydrolysis. Besides, a small peak appearing at $1633 \mathrm{~cm}^{-1}$ after COS hydrolysis can be attributed to the bending vibrations of $\mathrm{H}_{2} \mathrm{O}$ from the interlayer water (Yi et al. 2011), which accumulated in the used $\mathrm{Mg}_{2} \mathrm{Al}$-Cl-LDH owing to its low adsorption energy of $-0.78 \mathrm{eV}$ as shown in Fig. 2A3. These results demonstrate that the experimental data of $\mathrm{Mg}_{2} \mathrm{Al}-\mathrm{Cl}-\mathrm{LDH}$ are well in accordance with the above theoretical calculations for COS hydrolysis.

\section{Conclusion}

In summary, the COS hydrolysis over model $\mathrm{Mg}_{2} \mathrm{Al}-\mathrm{Cl}-\mathrm{LDH}$ was studied to make clear the catalytic mechanism of intercalated chlorine anions as active basic sites by both theoretical and experimental methods. The adsorption of reactants at different sites on ( $\left.\begin{array}{llll}0 & 0\end{array}\right)$ face of $\mathrm{Mg}_{2} \mathrm{Al}-\mathrm{Cl}$-LDH by DTF calculations found that the chloride ions in $\mathrm{LDH}$ can significantly activate the adsorbed $\mathrm{H}_{2} \mathrm{O}$ to enlarge the $L_{\mathrm{O}-\mathrm{H}}$ and $\theta_{\mathrm{H}-\mathrm{O}-\mathrm{H}}$ in $\mathrm{H}_{2} \mathrm{O}$ from $0.98 \AA$ and $104.6 \bigotimes$ in original $\mathrm{H}_{2} \mathrm{O}$ to $1.00 \AA$ and $110.9 \otimes$ in adsorbed $\mathrm{H}_{2} \mathrm{O}$, respectively. The adsorption of $\mathrm{H}_{2} \mathrm{O}\left(E_{a b s}:-0.78 \sim-0.69 \mathrm{eV}\right)$ is much stronger than COS $\left(E_{a b s:}: 0.24 \sim-0.19\right.$ $\mathrm{eV}$ ), but $\mathrm{H}_{2} \mathrm{O}$ and COS will still preferentially coadsorb ( $E_{a b s}:-0.81 \sim-0.86 \mathrm{eV}$ ) on $\mathrm{Mg}_{2} \mathrm{Al}-\mathrm{Cl}-\mathrm{LDH}$ through the Langmuir-Hinshelwood mechanism for further hydrolysis reaction. Moreover, the $\mathrm{Cl}$ ions in $\mathrm{LDH}$ can function as the Brønsted-base sites to take in the $\mathrm{H}$ atoms from MTA/HTA and facilitate their dissociative adsorption to form MT/HT HCl. The easy dissociation equilibrium may exist between MTA/HTA and $\mathrm{MT} / \mathrm{HT} \sim \mathrm{HCl}$ on $\mathrm{LDH}$ owing to the low energy barriers $(<0.5 \mathrm{eV})$, and the dissociated $\mathrm{MT} / \mathrm{HT} \sim \mathrm{HCl}$ will be the dominant intermediates on LDH with much lower adsorption energies $(-1.49 \sim-0.76 \mathrm{eV})$ than MTA/HTA $(-1.42 \sim-0.69 \mathrm{eV})$. The further research about the reaction channels found that the $\mathrm{Cl}$ ions also act as the Brønsted-base site and participate in the formation of transient states and subsequent hydrogen transfer process during COS hydrolysis to lower down the energy barriers. COS hydrolysis will preferentially go through the dissociated intermediates of $\mathrm{MT} / \mathrm{HT} \sim \mathrm{HCl}$ with dramatically decreased energy barriers $(0.08 \sim 0.79 \mathrm{eV})$ than MTA/HTA $(1.78 \sim 2.12 \mathrm{eV})$, and the rate-determining step of COS 
hydrolysis over $\mathrm{Mg}_{2} \mathrm{Al}-\mathrm{Cl}-\mathrm{LDH}$ will be the nucleophilic addition of $\mathrm{C}=\mathrm{O}$ in $\mathrm{COS}$ by $\mathrm{H}_{2} \mathrm{O}(E a=1.10 \mathrm{eV})$. The experimental results showed that the activity of the as-synthesized $\mathrm{Mg}_{2} \mathrm{Al}-\mathrm{Cl}-\mathrm{LDH}$ increases rapidly above $50^{\circ} \mathrm{C}$ and reaches $100 \%$ COS conversion at $130^{\circ} \mathrm{C}$ with the apparent activation energy of $0.89 \mathrm{eV}$ for COS hydrolysis, which is close to the calculated theoretical value of $1.10 \mathrm{eV}$. The accumulated intermediate products including the $\mathrm{MT}, \mathrm{HT}$, or carbonate can also be observed in the used $\mathrm{Mg}_{2} \mathrm{Al}-\mathrm{Cl}-\mathrm{LDH}$ by FT-IR with the very strong peaks around $1363 \mathrm{~cm}^{-1}$, which is well in accordance with the theoretical prediction about the dissociative adsorption of MTA and HTA.

\section{Declarations}

Ethics approval and consent to participate: Not applicable.

Consent for publication: Not applicable.

Competing interests: The authors declare that they have no competing interests.

Availability of data and materials: All data generated or analysed during this study are included in this published article.

Funding: This work was supported by Natural Science Foundation of China (Grant 21601192).

Authors' contributions: Academic idea, DFT calculation and original draft preparation by C. Li; Experiment and characterization by S. Zhao; Calculation model and methods by S. Xu; Suggestions by L. He, X. Yao and X. Shen; Modification and supervision by Z. Yao.

Supplementary information: Partial data of adsorption and reaction were provided in the Supplementary Information file.

\section{References}

Aboulayt A, Mauge F, Hoggan PE, Lavalley JC (1996) Combined FTIR, reactivity and quantum chemistry investigation of COS hydrolysis at metal oxide surfaces used to compare hydroxyl group basicity. Catal Lett 39:213-218

Anglada JM, Bofill JM (1998) How good is a broyden-fletcher-goldfarb-shanno-like update hessian formula to locate transition structures? Specific reformulation of broyden-fletcher-goldfarb-shanno for optimizing saddle points. J Comput Chem 19:349-362

Bajdich M, García-Mota M, Vojvodic A, Nørskov JK, Bell AT (2013) Theoretical investigation of the activity of cobalt oxides for the electrochemical oxidation of water. J Am Chem Soc 135:13521-13530

Benhiti R, Ait Ichou A, Zaghloul A, Aziam R, Carja G, Zerbet M, Sinan F, Chiban M (2020) Synthesis, characterization, and comparative study of MgAl-LDHs prepared by standard coprecipitation and urea 
hydrolysis methods for phosphate removal. Environ Sci Pollut Res 27:45767-45774

Bing W, Zheng L, He S, Rao D, Xu M, Zheng L, Wang B, Wang Y, Wei M (2018) Insights on active sites of CaAl-hydrotalcite as a high-performance solid base catalyst toward Aldol Condensation. ACS Catal 8:656664

Chaillot D, Bennici S, Brendlé J (2020) Layered double hydroxides and LDH-derived materials in chosen environmental applications: A review. Environ Sci Pollut Res 28:24375-24405

Cheng Y, Zhang C, Zhang Y, Zhang H, Sun X, Mu Y (2015) Characteristics and anthropogenic sources of carbonyl sulfide in Beijing. J Environ Sci 28:163-170

Chiche D, Schweitzer J-M (2017) Investigation of competitive COS and HCN hydrolysis reactions upon an industrial catalyst: Langmuir-Hinshelwood kinetics modeling. Appl Catal B 205:189-200

Costa DG, Rocha AB, Souza WF, Chiaro SSX, Leitão AA (2012) Comparative structural, thermodynamic and electronic analyses of $\mathrm{Zn}-\mathrm{Al}-\mathrm{A}^{\mathrm{n}-}$ hydrotalcite-like compounds $\left(\mathrm{A}^{\mathrm{n}-}=\mathrm{Cl}^{-}, \mathrm{F}^{-}, \mathrm{Br}^{-}, \mathrm{OH}^{-}, \mathrm{CO}_{3}{ }^{2-}\right.$ or $\left.\mathrm{NO}_{3}{ }^{-}\right)$: An ab initio study. Appl Clay Sci 56:16-22

Deng C, Li Q-G, Ren Y, Wong N-B, Chu S-Y, Zhu H-J (2007) A comprehensive theoretical study on the hydrolysis of carbonyl sulfide in the neutral water. J Comput Chem 29:466-480

Fiedorow R, Leaute R, Dalla Lana IG (1984) A study of the kinetics and mechanism of carbonyl sulfide hydrolysis over alumina. J Catal 85:339-348

García-Mota M, Bajdich M, Viswanathan V, Vojvodic A, Bell AT, Nørskov JK (2012) Importance of correlation in determining electrocatalytic oxygen evolution activity on cobalt oxides. J Phys Chem C 116:21077-21082

George ZM (1974) Effect of catalyst basicity for carbonyl sulfide-sulfur dioxide and carbonyl sulfide hydrolysis reactions. J Catal 35:218-224

Guo H, Tang L, Li K, Ning P, Sun X, Liu G, Bao S, Zhu T, Jin X, Duan Z, Li Q (2016) The hydrolysis mechanism and kinetic analysis for COS hydrolysis: A DFT study. Russ J Phys Chem B 10:427-434

Guo X, Zhang F, Peng Q, Xu S, Lei X, Evans DG, Duan X (2011) Layered double hydroxide/eggshell membrane: An inorganic biocomposite membrane as an efficient adsorbent for $\mathrm{Cr}(\mathrm{VI})$ removal. Chem Eng J 166:81-87

Harnisch J, Borchers R, Fabian P, Kourtidis K (1995) Aluminium production as a source of atmospheric carbonyl sulfide (COS). Environ Sci Pollut Res 2:161-162

Hou X-J, Li H, He P, Sun Z, Li S (2017) Structural and electronic analysis of Li/Al layered double hydroxides and their adsorption for $\mathrm{CO}_{2}$. Appl Surf Sci 416:411-423

Page $13 / 25$ 
Jaymand M (2011) Synthesis and characterization of an exfoliated modified syndiotactic polystyrene/Mg-Al-layered double-hydroxide nanocomposite. Polym J 43:186-193

Labaki M, Jeguirim M (2017) Thermochemical conversion of waste tyres - a review. Environ Sci Pollut Res 24:9962-9992

Li K, Wang C, Ning P, Li K, Sun X, Song X, Mei Y (2020) Surface characterization of metal oxidessupported activated carbon fiber catalysts for simultaneous catalytic hydrolysis of carbonyl sulfide and carbon disulfide. J Environ Sci 96:44-54

Liu, He H, Xu, Yu (2007) Mechanism of heterogeneous reaction of carbonyl sulfide on magnesium oxide. J Phys Chem A 111:4333-4339

Liu H-M, Zhao X-J, Zhu Y-Q, Yan H (2020) DFT study on MgAl-layered double hydroxides with different interlayer anions: Structure, anion exchange, host-guest interaction and basic sites. Phys Chem Chem Phys 22:2521-2529

Liu Q, Wang B, Wang C, Tian Z, Qu W, Ma H, Xu R (2014) Basicities and transesterification activities of Zn-Al hydrotalcites-derived solid bases. Green Chem 16:2604-2613

Mi J, Chen X, Zhang Q, Zheng Y, Xiao Y, Liu F, Au C-T, Jiang L (2019) Mechanochemically synthesized MgAl layered double hydroxide nanosheets for efficient catalytic removal of carbonyl sulfide and $\mathrm{H}_{2} \mathrm{~S}$. Chem Commun 55:9375-9378

Moraes PIR, Tavares SR, Vaiss VS, Leitão AA (2016) Ab initio study of layered double hydroxides containing iron and its potential use as fertilizer. J Phys Chem C 120:9965-9974

Ning P, Song X, Li K, Wang C, Tang L, Sun X (2017) Catalytic hydrolysis of carbonyl sulphide and carbon disulphide over $\mathrm{Fe}_{2} \mathrm{O}_{3}$ cluster: Competitive adsorption and reaction mechanism. Sci Rep 7:1-9

Nobeli I, Laskowski RA, Valdar WSJ, Thornton JM (2001) On the molecular discrimination between adenine and guanine by proteins. Nucleic Acids Res 29:4294-4309

Payne MC, Teter MP, Allan DC, Arias TA, Joannopoulos JD (1992) Iterative minimization techniques for ab initio total-energy calculations: Molecular dynamics and conjugate gradients. Rev Mod Phys 64:10451097

Perdew JP, Burke K, Ernzerhof M (1996) Generalized gradient approximation made simple. Phys Rev Lett 77:3865-3868

Rao KK, Gravelle M, Valente JS, Figueras F (1998) Activation of MgAl hydrotalcite catalysts for Aldol Condensation reactions. J Catal 173:115-121 
Rhodes C, Riddel SA, West J, Williams BP, Hutchings GJ (2000) The low-temperature hydrolysis of carbonyl sulfide and carbon disulfide: A review. Catal Today 59:443-464

Ryzhikov A, Hulea V, Tichit D, Leroi C, Anglerot D, Coq B, Trens P (2011) Methyl mercaptan and carbonyl sulfide traces removal through adsorption and catalysis on zeolites and layered double hydroxides. Appl Catal A 397:218-224

Segall MD, Lindan PJD, Probert MJ, Pickard CJ, Hasnip PJ, Clark SJ, Payne MC (2002) First-principles simulation: Ideas, illustrations and the CASTEP code. J Phys: Condens Matter 14:2717-2744

Song X, Ning P, Wang C, Li K, Tang L, Sun X (2017) Catalytic hydrolysis of COS over $\mathrm{CeO}_{2}$ (110) surface: A density functional theory study. Appl Surf Sci 414:345-352

Song X, Sun L, Guo H, Li K, Sun X, Wang C, Ning P (2019) Experimental and theoretical studies on the influence of carrier gas for COS catalytic hydrolysis over MgAlCe composite oxides. ACS Omega 4:71227127

Svoronos PDN, Bruno TJ (2002) Carbonyl sulfide: A review of its chemistry and properties. Ind Eng Chem Res 41:5321-5336

Taylor HJMM (1973) Crystal structures of some double hydroxide minerals. Mineral Mag 39:377-389

Tkatchenko A, Scheffler M (2009) Accurate molecular van der Waals interactions from ground-state electron density and free-atom reference data. Phys Rev Lett 102:073005

Toops TJ, Crocker M (2008) New sulfur adsorbents derived from layered double hydroxides: II. DRIFTS study of COS and $\mathrm{H}_{2} \mathrm{~S}$ adsorption. Appl Catal B 82:199-207

Valdés Á, Qu ZW, Kroes GJ, Rossmeisl J, Nørskov JK (2008) Oxidation and photo-oxidation of water on $\mathrm{TiO}_{2}$ surface. J Phys Chem C 112:9872-9879

Wang H, Yi H, Tang X, Ning P, Yu L, He D, Zhao S, Li K (2012) Catalytic hydrolysis of COS over calcined CoNiAl hydrotalcite-like compounds modified by cerium. Appl Clay Sci 70:8-13

Wang J, Lei Z, Qin H, Zhang L, Li F (2011) Structure and catalytic property of Li-Al metal oxides from layered double hydroxide precursors prepared via a facile solution route. Ind Eng Chem Res 50:7120-7128

Winter F, van Dillen AJ, de Jong KP (2005) Supported hydrotalcites as highly active solid base catalysts. Chem Commun 31:3977-3979

Winter F, Xia X, Hereijgers BPC, Bitter JH, van Dillen AJ, Muhler M, de Jong KP (2006) On the nature and accessibility of the Brønsted-base sites in activated hydrotalcite catalysts. J Phys Chem B 110:9211-9218 
Yan H, Wei M, Ma J, Evans DG, Duan X (2010) Plane-wave density functional theory study on the structural and energetic properties of cation-disordered $\mathrm{Mg}-\mathrm{Al}$ layered double hydroxides. J Phys Chem $\mathrm{A}$ 114:7369-7376

Yao Z, Jiang X, Shen X, Ye Y, Cao X, Zhang Y, He K (2015) On-road emission characteristics of carbonyl compounds for heavy-duty diesel trucks. Aerosol Air Qual Res 15:915-925

Yi H, Wang H, Tang X, Ning P, Yu L, He D, Zhao S (2011) Effect of calcination temperature on catalytic hydrolysis of COS over CoNiAl catalysts derived from hydrotalcite precursor. Ind Eng Chem Res 50:1327313279

Yue X, Liu W, Chen Z, Lin Z (2017) Simultaneous removal of $\mathrm{Cu}(\mathrm{II})$ and $\mathrm{Cr}(\mathrm{VI})$ by $\mathrm{Mg}-\mathrm{Al}-\mathrm{Cl}$ layered double hydroxide and mechanism insight. J Environ Sci 53:16-26

Zhao S, Kang D, Liu Y, Wen Y, Xie X, Yi H, Tang X (2020) Spontaneous formation of asymmetric oxygen vacancies in transition-metal-doped $\mathrm{CeO}_{2}$ nanorods with improved activity for carbonyl sulfide hydrolysis. ACS Catal 10:11739-11750

Zhao S, Yi H, Tang X, Jiang S, Gao F, Zhang B, Zuo Y, Wang Z (2013a) The hydrolysis of carbonyl sulfide at low temperature: A review. Sci World J 45:739501-739509

Zhao S, Yi H, Tang X, Song C (2013b) Low temperature hydrolysis of carbonyl sulfide using Zn-Al hydrotalcite-derived catalysts. Chem Eng J 226:161-165

\section{Figures}



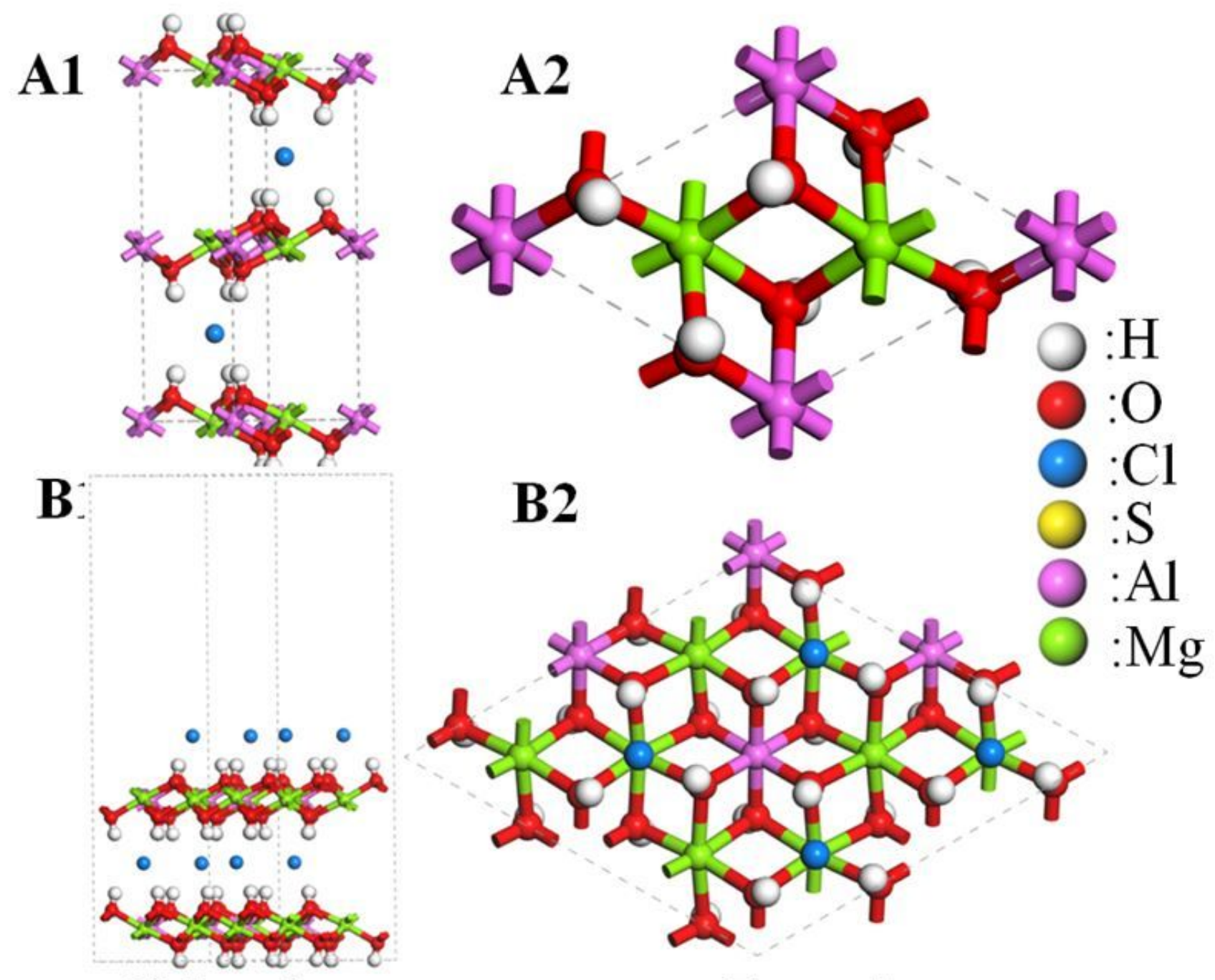

\section{Side view}

\section{Top view}

Figure 1

The geometrically optimized model of Mg2AI-Cl-LDH unit cell $(A 1, A 2)$ and its $\left(\begin{array}{ll}0 & 0\end{array}\right)$ face with $p(2 \times 2 \times 1)$ supercells (B1, B2). 

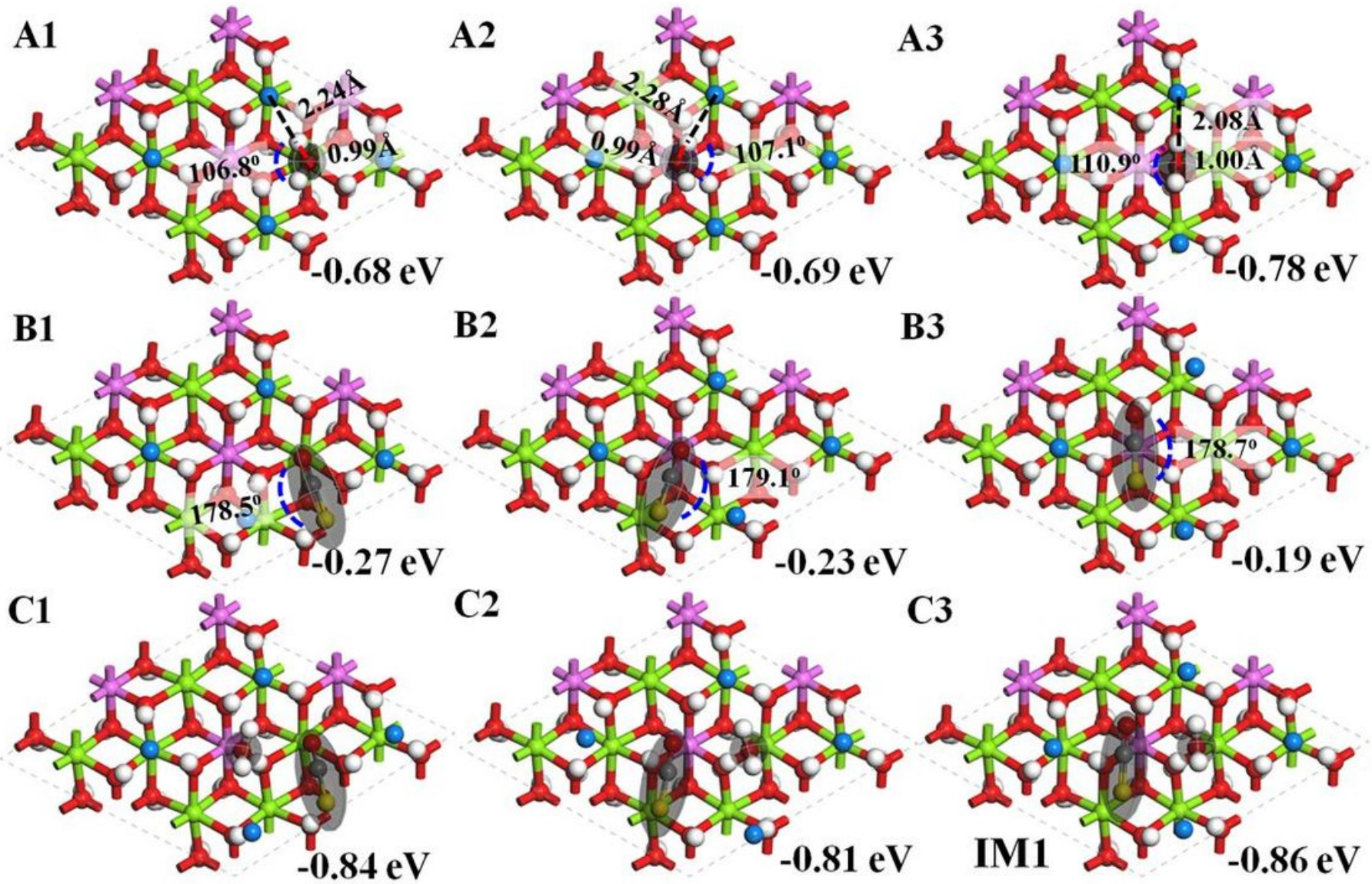

Figure 2

The geometrically optimized configurations of H2O (A1-A3), COS (B1-B3) and H2O/COS (C1-C3) adsorbed at the different sites on $\left(\begin{array}{lll}0 & 0 & 3\end{array}\right)$ face of Mg2Al-Cl-LDH from top view with their adsorption energy labeled. (Atomic legend: $-\mathrm{Cl},-\mathrm{C},-\mathrm{S},-\mathrm{H},-\mathrm{O},-\mathrm{Al},-\mathrm{Mg}$.) 


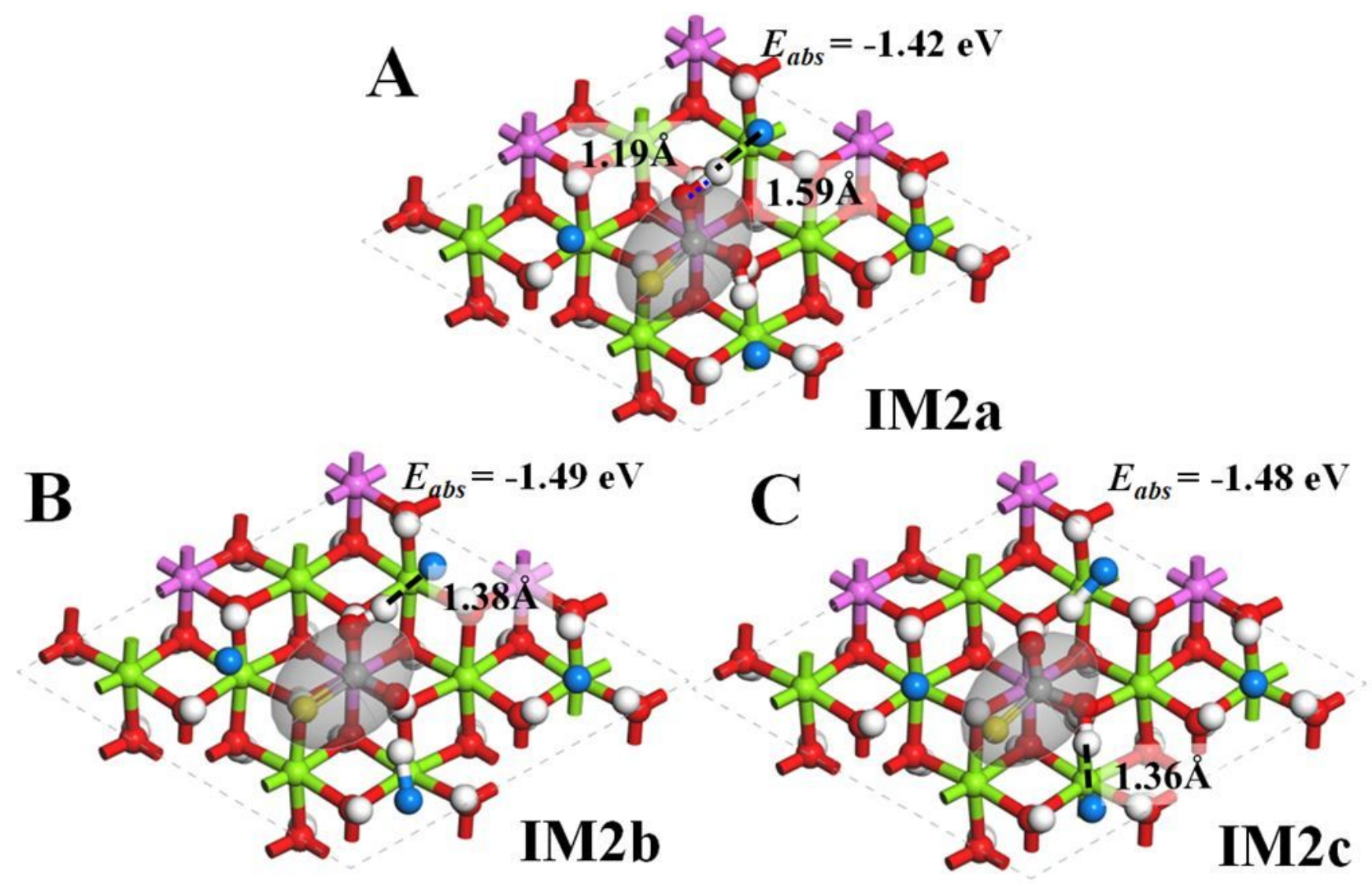

Figure 3

The different geometrical configurations of MTA $(A)$ and its two dissociative adsorption products of MT $\sim \mathrm{HCl}(\mathrm{B}, \mathrm{C})$ on the $\left(\begin{array}{lll}0 & 0 & 3\end{array}\right)$ face of Mg2Al-Cl-LDH from top view together with their adsorption energies labeled. IM2a IM2C are the serial numbers of the possible intermediates during COS hydrolysis, which are labeled at the bottom right of each adsorption configuration. (Atomic legend: $-\mathrm{Cl},-\mathrm{C},-\mathrm{S},-\mathrm{H},-\mathrm{O},-\mathrm{Al},-\mathrm{Mg}$.) 

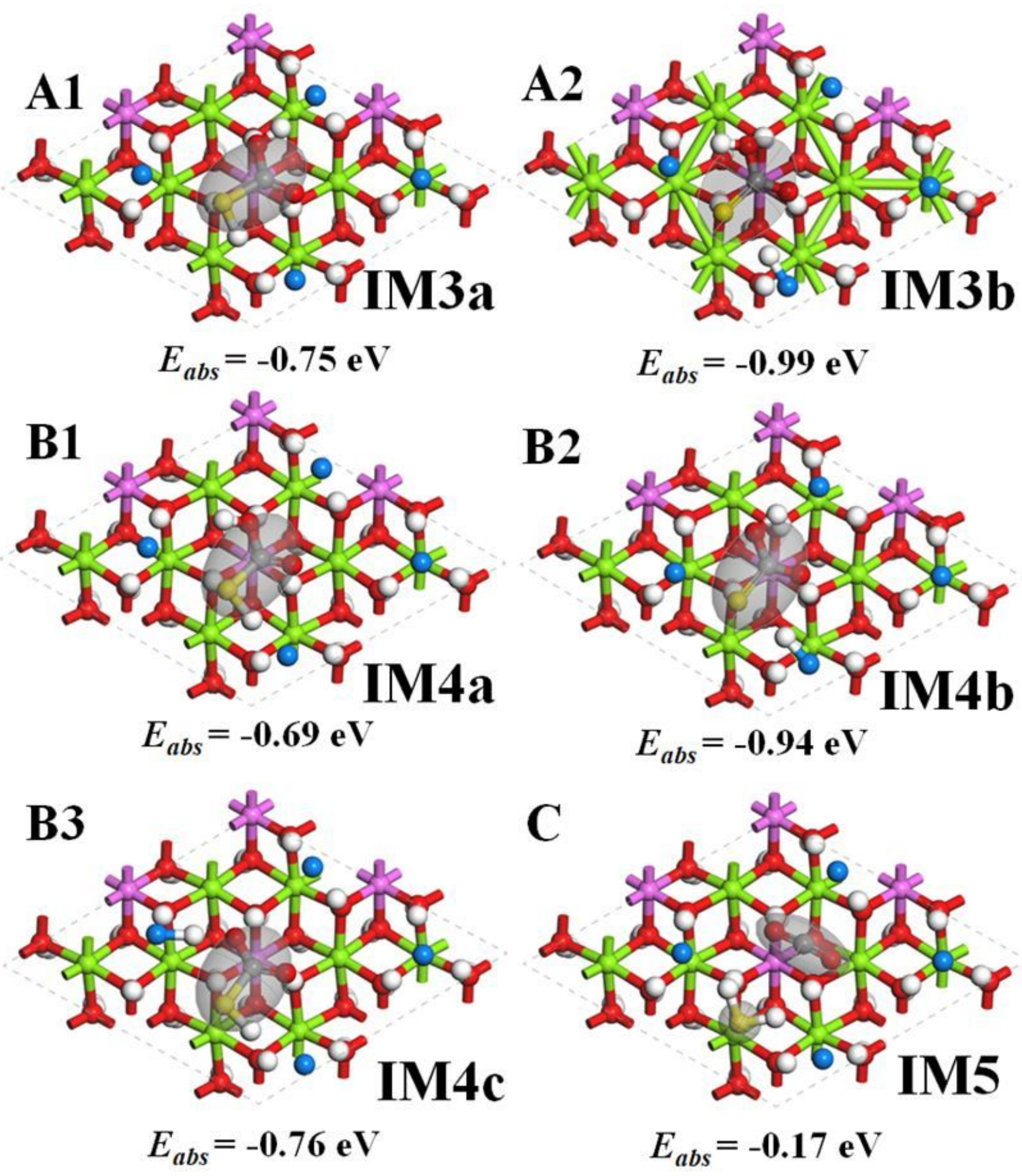

Figure 4

The different geometrical configurations of $\mathrm{HTA}(\mathrm{A} 1, \mathrm{~B} 1)$, their possible dissociative adsorption products of $\mathrm{HT} \sim \mathrm{HCl}(\mathrm{A} 2, \mathrm{~B} 2, \mathrm{~B} 3)$, and the final hydrolysis products $(\mathrm{H} 2 \mathrm{~S}$ and $\mathrm{CO} 2)$ adsorbed on the $(0 \mathrm{O} 3)$ face of Mg2Al-Cl-LDH from top view together with their adsorption energies labeled. IM3a IM5 are the serial numbers of the possible intermediates during COS hydrolysis, which are labeled at the bottom right of each adsorption configuration. (Atomic legend: - $\mathrm{Cl},-\mathrm{C},-\mathrm{S},-\mathrm{H},-\mathrm{O},-\mathrm{Al},-\mathrm{Mg}$.) 


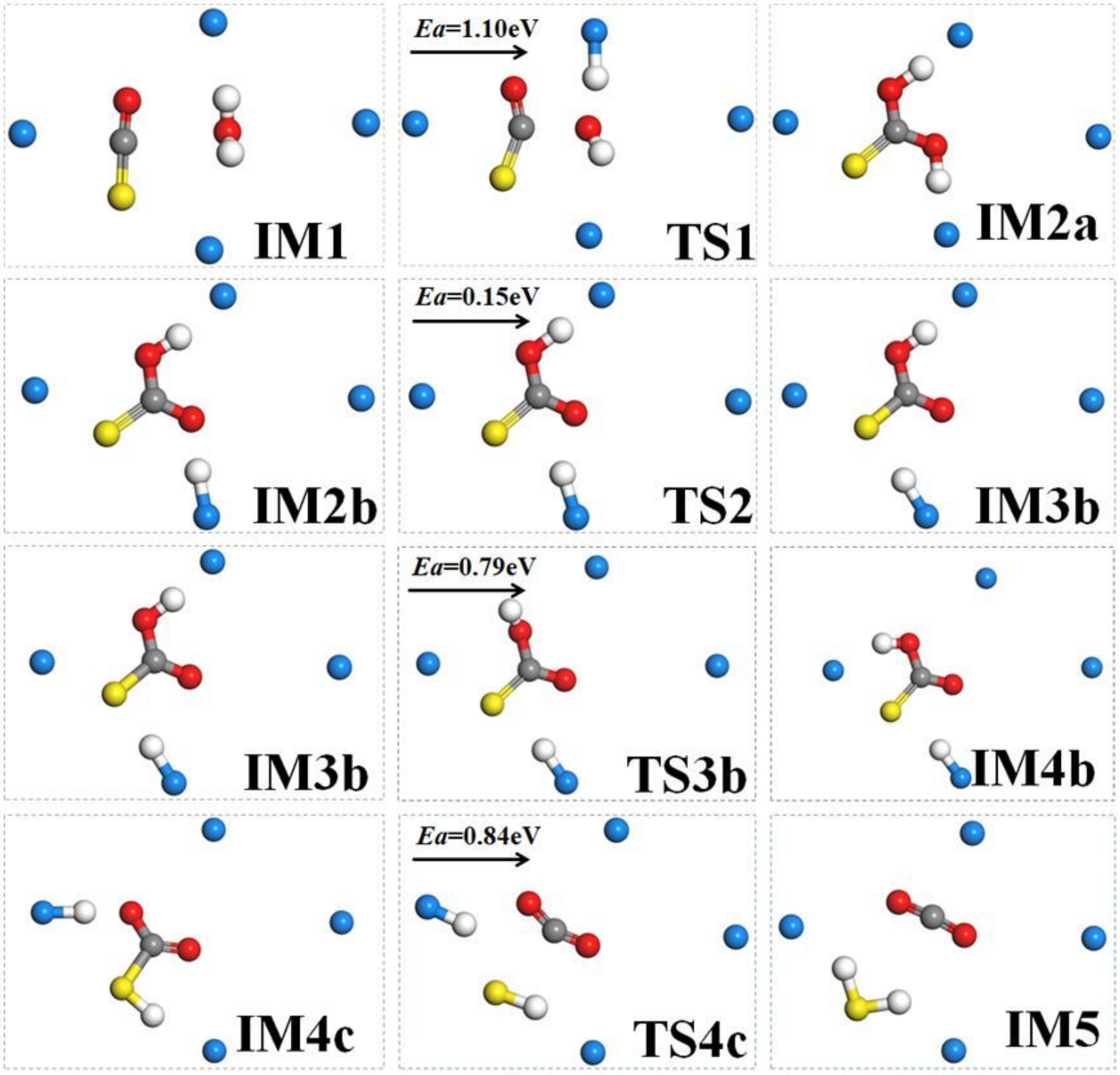

Figure 5

The transient states and activation energies of the reaction channel through the dissociated $\mathrm{MT} \sim \mathrm{HCl}$ and $\mathrm{HT} \sim \mathrm{HCl}$ for COS hydrolysis over the $\left(\begin{array}{lll}0 & 0 & 3\end{array}\right)$ face of Mg2Al-Cl-LDH. (Atomic legend: $-\mathrm{Cl},-\mathrm{C},-\mathrm{S},-\mathrm{H},-\mathrm{O}$. The elements in layer of LDH are not shown.) 


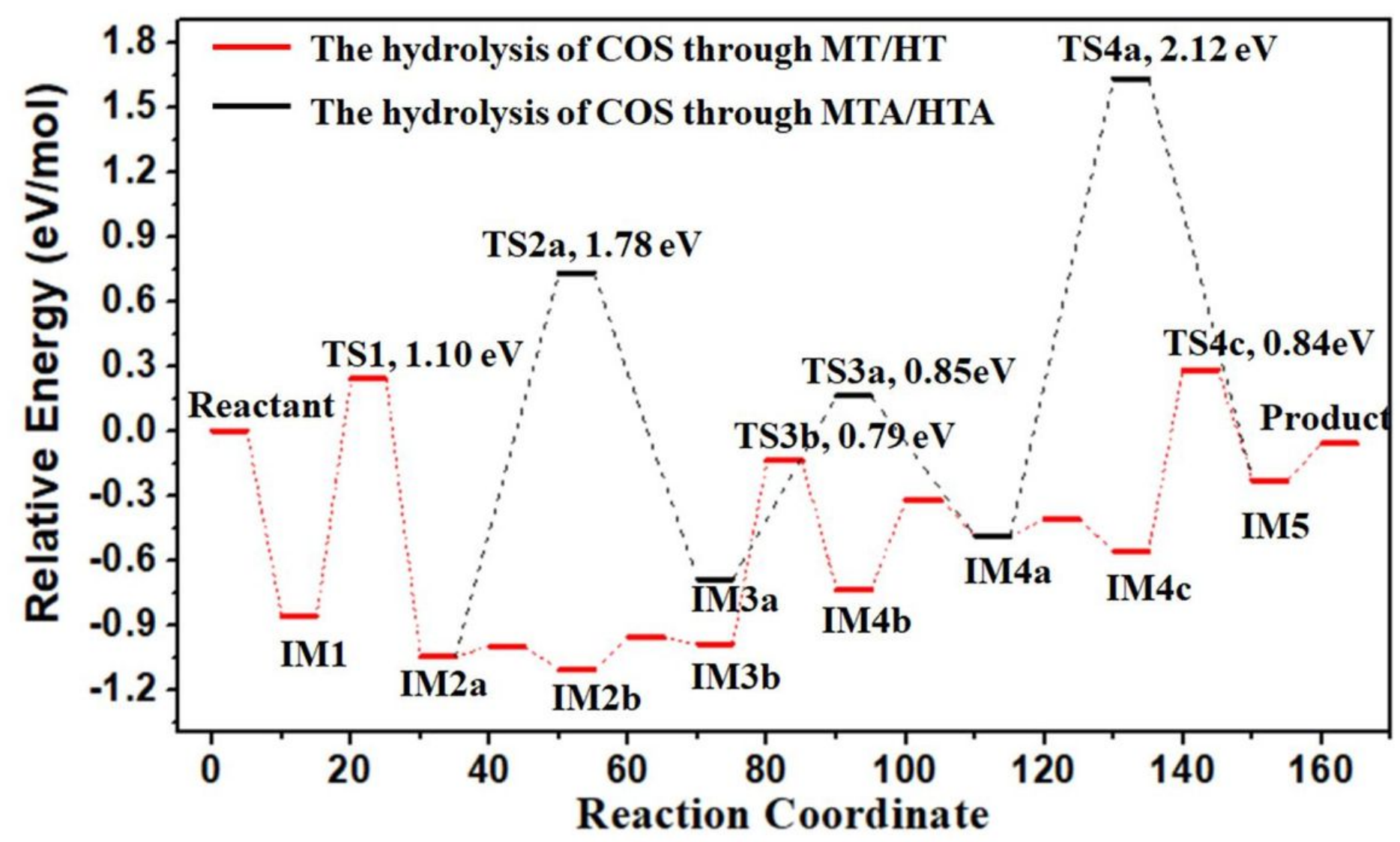

Figure 6

The reaction channels for COS hydrolysis through the routes of MT/HT or MTA/HTA. 


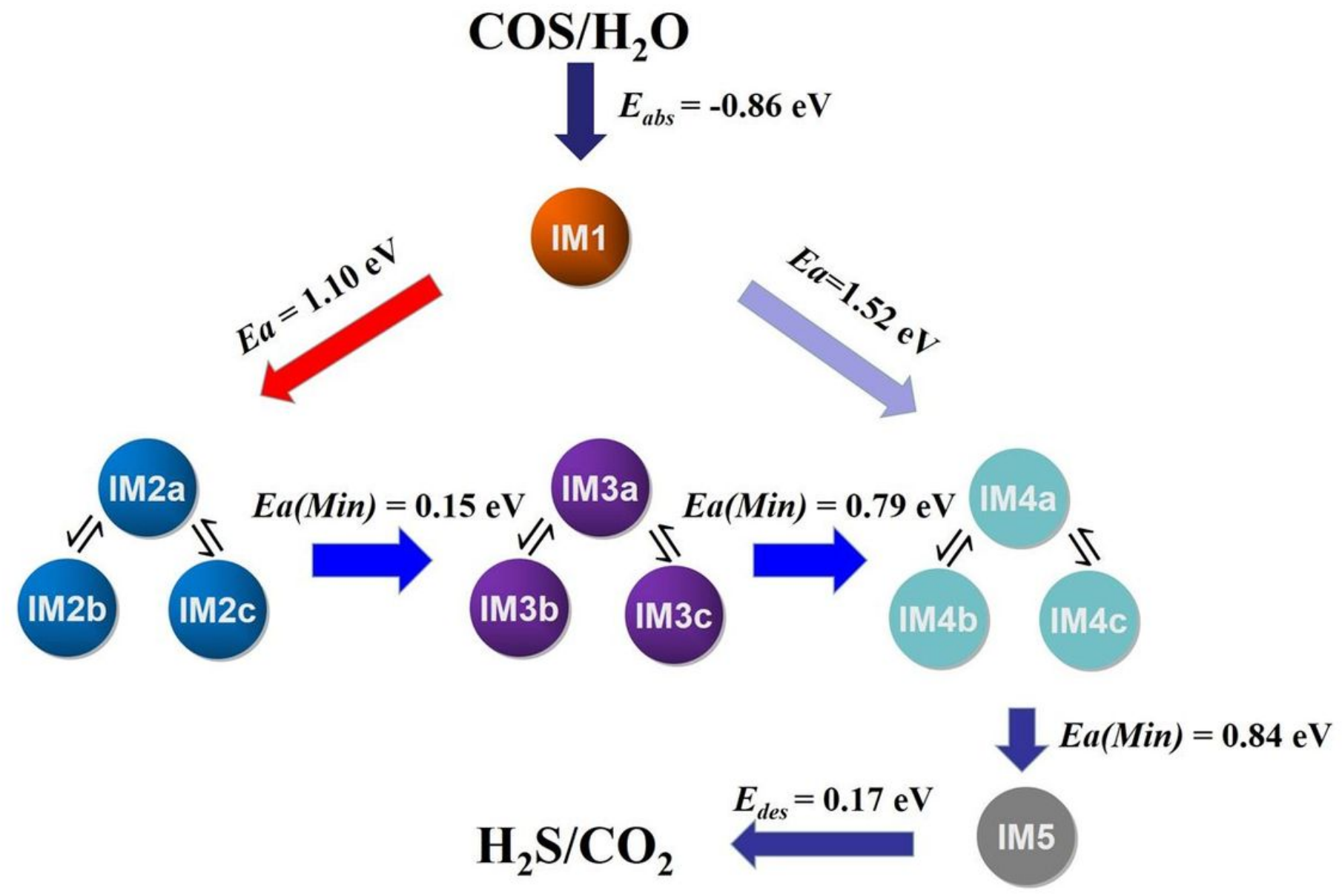

Figure 7

The total reaction networks including the intermediates of dissociated $\mathrm{MT} \sim \mathrm{HCl}$ and $\mathrm{HT} \sim \mathrm{HCl}$ for $\mathrm{COS}$

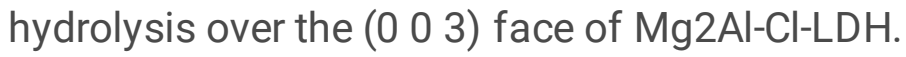



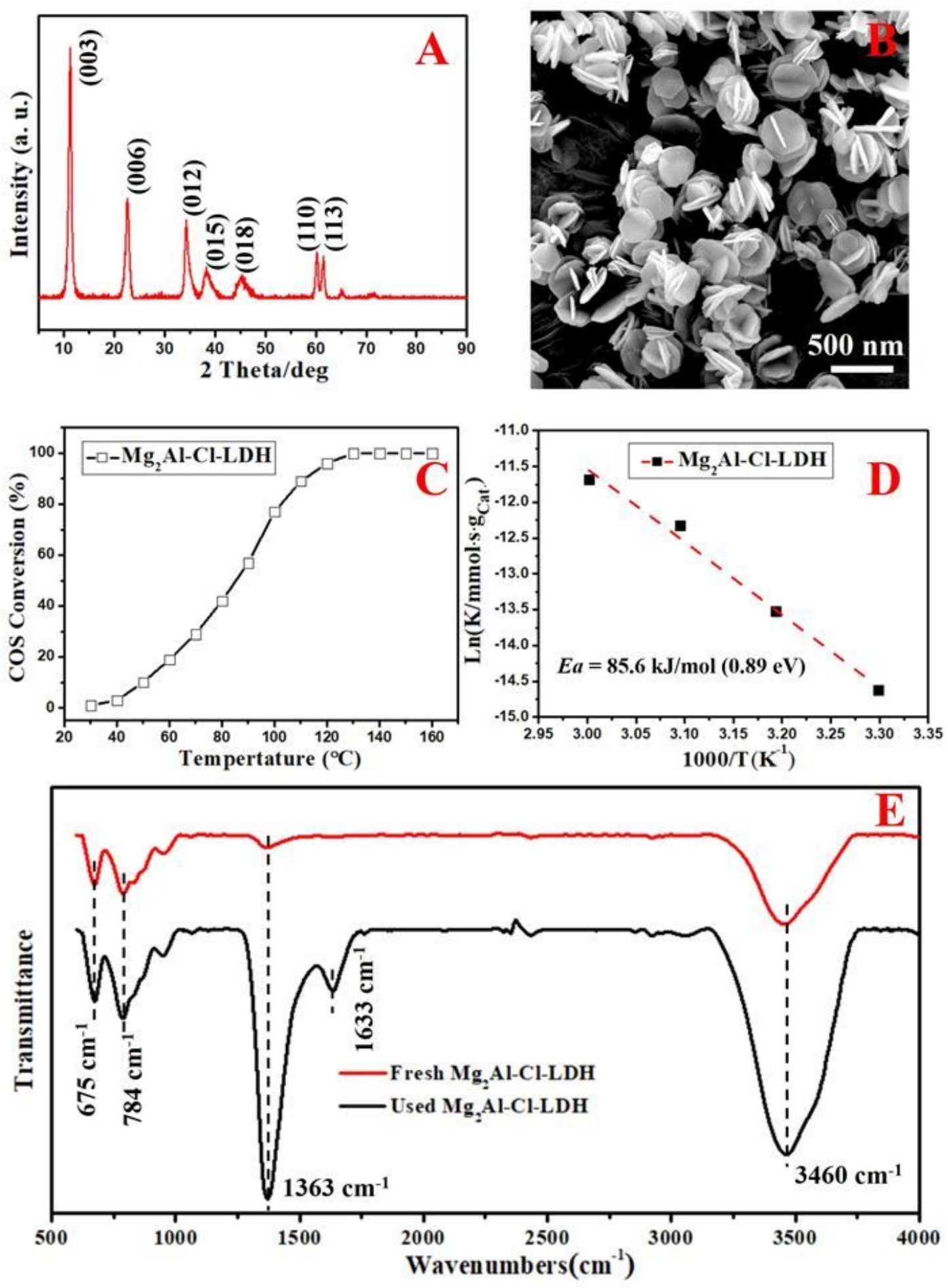

Figure 8

The structure and properties of the as-synthesized Mg2Al-Cl-LDH. A) the XRD pattern of Mg2Al-Cl-LDH, B) SEM image of Mg2Al-Cl-LDH, C) COS conversion over Mg2Al-Cl-LDH, D) Arrhenius plots of COS hydrolysis over Mg2Al-Cl-LDH, E) the FT-IR spectrums of fresh and used Mg2Al-Cl-LDH samples.

\section{Supplementary Files}


This is a list of supplementary files associated with this preprint. Click to download.

- SupplementaryMaterialESPR.docx 